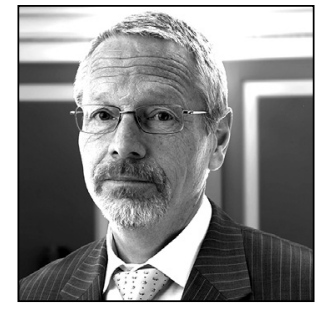

Kåre Lilleholt

Professor

University of Oslo

\title{
A Half-built House? The New Consumer Sales Directive Assessed as Contract Law
}

\section{Introduction}

The article discusses some aspects of the total harmonisation objective of the new consumer sales directive (hereinafter SGD). ${ }^{* 1}$ The purpose of the directive is to 'contribute to the functioning of the internal market' (Article 1). As cross-border consumer contracts are usually governed by the law of the country where the consumer has his or her habitual residence, ${ }^{*}{ }_{2}$ sellers offering goods to consumers in other countries than their own must be prepared to deal under different contract law regimes. This may lead to additional costs, something that may make cross-border contracting less attractive. ${ }^{*}{ }^{3}$ The SGD is therefore a total harmonisation directive, meaning that, as a rule, consumers may not be given either stronger or weaker protection under national law regarding the issues regulated by the directive. ${ }^{*}$ The 1999 consumer sales directive which will be repealed by the SGD - is a minimum harmonisation directive; member states are free to maintain or introduce more consumer-friendly rules but not less protective rules. ${ }^{{ }^{5}}$ The total harmonisation principle of the new directive can necessarily not give the consumers stronger protection than a minimum harmonisation directive would have done. The effect of the total harmonisation principle must therefore be measured by the extent to which more legal certainty for sellers has been achieved.

Not surprisingly, the new directive bears the mark of many compromises, several of them resulting from the legislative process in the Parliament. On some issues, member states today have more stringent rules on consumer protection than the ones proposed by the Commission, and reduction of consumer protection will naturally lead to political discussions. The final text of the SGD allows for national laws varying the rules of the directive (for example, the time limit for the seller's liability), as well as national laws deviating from the rules of the directive (for example, specific remedies for certain hidden effects and a remedy in the form of rejecting the goods). In addition, the directive explicitly allows for national rules on issues not covered or only partly covered by the directive (for example, formation and invalidity of contracts, effects of termination). Not explicitly mentioned is the obvious gap that must be filled by national laws because

1 Directive (EU) 2019/771 of the European Parliament and of the Council on certain aspects concerning contracts for the sale of goods.

2 Regulation (EC) 593/2008 of the European Parliament and of the Council of 17 June 2008 on the law applicable to contractual obligations (Rome I); see, in particular, Article 6.

3 SGD, Recital 7.

4 Directive 1999/44/EC of the European Parliament and of the Council of 25 May 1999 on certain aspects of the sale of consumer goods and associated guarantees, Article 8, para 2.

5 SGD, Article 4. 
the directive offers no rules on the consumer's obligations or remedies for non-performance of such obligations. A cross-border seller must be prepared for varying regimes concerning, for example, late payment of the agreed price. Some of the compromises and regulatory gaps mentioned here will be illustrated in a little more detail below.

The fact that regulation of a contractual relationship is incomplete is, of course, nothing new in EU legislation on consumer contracts, but this trait becomes more visible in a directive with the objective of total harmonisation - albeit a 'targeted' total harmonisation. The intended foreseeability for sellers venturing into cross-border sales is undermined by the incompleteness of the rules.

The proposal for a regulation on a common European sales law (hereinafter CESL) had a much wider scope, including, inter alia, rules on formation and validity of contracts and on the obligations of the buyer. ${ }^{* 6}$ Even that proposal was incomplete, assessed as contract law, and would have had to be supplemented by national laws; only national legal systems can have the quality of being in principle exhaustive. The CESL turned out to be politically unacceptable and was withdrawn by the Commission. The many amendments to the SGD in the legislative process in the Parliament illustrate that even this more modest harmonisation is controversial.

\section{Rules that may be varied by national law}

Perhaps the most important example of the directive allowing for national legislation that varies the rule of the directive is related to the time limits for the seller's liability for lack of conformity. According to the SGD's Article 10, para 1, the seller shall be liable for 'any lack of conformity which exists at the time when the goods were delivered and which becomes apparent within two years of that time'.

This two-year limit was a firm rule in the Commission's proposal and would have meant that longer limits for the seller's liability were not allowed. ${ }^{*} 7$ This was politically controversial, as it would lead to reduced consumer protection in some member states. Among these were Sweden, where the time limit is three years, and the EEA states Iceland and Norway, where it is five years for goods that are meant to last considerably longer than two years. ${ }^{* 8}$ Apart from this, such time limits may be inapplicable in several states in cases of fraud or violation of duties of good faith and fair dealing. In the Parliament, the provision in Article 10 was amended to the effect that member states may 'maintain or introduce' longer time limits (para 3). Member states are also allowed to rely only on general limitation periods (para 5) and, further, to allow contract terms reducing liability periods or limitation periods to one year for second-hand goods (para 6).

This means that the seller must be prepared to be liable for lack of conformity for a longer period than two years, depending on national legislation in each country. Such legislation is normally mandatory, and the seller should adjust his or her general contract conditions accordingly.

\section{Where national law may deviate from the model of the directive}

The SGD allows for national rules on 'specific remedies' in certain cases. These are remedies that are not included in the directive (a right to reject) or remedies that may be chosen outside the 'hierarchy' of remedies prescribed by the directive (specific remedies for certain 'hidden defects').

Article 3, para 7 of the SGD states that the directive 'shall not affect the freedom of the Member States to allow consumers to choose a specific remedy, if the lack of conformity becomes apparent within a period after delivery, not exceeding 30 days'. This opening for deviating national rules is obviously inspired by the

$6 \operatorname{COM}(2011) 635$ final, Proposal for a Regulation of the European Parliament and of the Council on a Common European Sales Law.

$7 \operatorname{COM}(2015) 635$ final, Proposal for a Directive of the European Parliament and of the Council on certain aspects concerning contracts for the online and other distance sales of goods, Article 14.

8 Sweden: konsumentköplag 1990:352 (Consumer Sales Act), Section 23; Iceland: lög um neytendakaup 2003 nr. 4820. mars (Consumer Sales Act), Section 27; Norway: lov 13. mai 1987 nr. 27 om kjøp (Sale of Goods Act), Section 27. 
common law rules on the right to reject the goods, ${ }^{*} 9$ and it was added as a result of the legislative process in the Parliament.

This right in English law to reject non-conforming goods without further requirements is a powerful remedy that in real terms implies a termination of the contract at an early stage. The right 'entitles the consumer to reject the goods and treat the contract as at an end'. ${ }^{\prime} 10$ This means that the consumer makes the goods available for the seller and that the seller must give the consumer a refund. ${ }^{*}{ }^{* 1}$ The remedy was kept in the Consumer Rights Act 2015 even though it is not part of the 1999 directive on consumer sales. ${ }^{*}$ Such a deviation from the directive was, of course, unproblematic under a minimum harmonisation regime, but it could not have been upheld under the new directive without a basis for derogation.

The other exception in Article 3, para 7 of the SGD makes it clear that the directive 'shall not affect national rules not specific to consumer contracts providing for specific remedies for certain types of defects that were not apparent at the time of conclusion of the sales contract'. This exception is obviously inspired by rules on legal guarantees against hidden defects that have their roots in Roman law, and that are still to be found, for example, in the French civil code. ${ }^{*} 3$ This basis for derogation, too, was added during the parliamentary process.

Under French law, a hidden defect that gravely affects the intended use of the goods may, on certain conditions, give the buyer a right to choose between two remedies, which largely correspond to the directive's termination and price reduction. In addition, the buyer may claim damages. These remedies are today regarded as alternatives to the remedies laid down in the legislation transposing the 1999 consumer sales directive. ${ }^{* 14}$ The point of this right to choose seems to be that the buyer does not have to accept cure by the seller in the form of repair or replacement.

These openings for deviating rules mean that a seller must be prepared to face a model of remedies different from the one of the SGD. The wording of Article 3, para 7 is broad enough to allow even specialities beyond the rules mentioned here, which inspired the exceptions.

\section{National rules of general contract law supplementing the directive}

The SGD 'shall not affect the freedom of Member States to regulate aspects of general contract law, such as rules on the formation, validity, nullity or effects of contracts, including the consequences of the termination of a contract, in so far as they are not regulated in this Directive, or the right to damages' (Article 3, para 6). This provision points to a vast range of rules that are not covered by the directive or are only partially covered by it. That is so even if one thinks only of sale of goods contracts, leaving aside all other contracts. The directive has a narrow scope, mainly limited to lack of conformity and remedies for such lack of conformity. Other rules regarding the contractual relationship in a contract for the sale of goods are mostly not harmonised by EU law. A few rules on delay and on passing of risk are harmonised in the consumer rights directive, in addition to the right of withdrawal. ${ }^{* 15}$ General rules on unfair terms in non-negotiated consumer contracts are laid down in the unfair contract terms directive. ${ }^{*}{ }^{16}$ Some rules of the consumer credit directive can affect the contractual relationship in consumer credit sales of goods. ${ }^{* 17}$ Apart from this, there is legislation regarding marketing, e-commerce, and information duties indirectly affecting consumer contracts for the sale of goods, but contractual effects, if any, of contravention of such legislation have mostly

\footnotetext{
In this connection, see the Consumer Rights Act 2015, sections 19(3), 20, and 22.

Consumer Rights Act 2015, Section 20(4).

1 Consumer Rights Act, Section 20(7).

12 For discussion, see P. Giliker, 'The Consumer Rights Act 2015 - a Bastion of European Consumer Rights?', Legal Studies, vol. 37, no. 1 2017, pp. 78-102 on pp. 86-88. - DOI: https://doi.org/10.1111/lest.12139.

13 French civil code, articles 1641-1649.

14 O. Barret, "Vente (3 effets)", Répertoire de droit civil (Dalloz online), Paris 2007 (2019) (http://www.dalloz.fr/), no. 535.

15 Directive 2011/83/EU of the European Parliament and of the Council of 25 October 2011 on consumer rights.

16 Council Directive 93/13/EEC of 5 April 1993 on unfair terms in consumer contracts.

17 Directive 2008/48/EC of the European Parliament and of the Council of 23 April 2008 on credit agreements for consumers.
} 
been left to national regulation. In sum, this means that the seller's rights and obligations may vary to a great extent, depending on general national law on contracts.

In most cases, questions of the binding effects of the contract are governed by the law of the country where the consumer has his or her habitual residence. ${ }^{*}{ }^{*}$ Here, only one example will be discussed in order to illustrate the close connection between rules on conformity and rules on the binding effect of contracts, namely invalidity because of the seller withholding information on the quality of the goods.

In Denmark, Finland, Iceland, Norway, and Sweden, the sale of goods acts have provisions to the effect that withholding of information may constitute non-conformity of the goods. This is the case if the seller has not disclosed to the buyer circumstances that the seller is expected to have known of and that the buyer had reason to expect to be informed about. In Denmark, the rule applies in consumer sales only, while it applies to all sale of goods contracts and even to some other contracts in the other countries. ${ }^{* 19}$ There is no such provision in the SGD. Under the directive, incorrect information may lead to non-conformity, but withheld information does not.

Under some national laws, withholding information - including information related to the quality of the goods - may lead to invalidity of a contract for mistake. However, such rules are not the same from country to country, ${ }^{*}{ }^{20}$ and there is no EU harmonisation at this point (under the proposal for a common European sales law, withholding information that good faith and fair dealing would have required a party to disclose could make the contract avoidable, per Article 48). Hence, the seller must be prepared to incur information duties with contractual consequences in some countries but not necessarily in all. Whether or not the Nordic countries - under a total harmonisation directive - can keep their rules on withholding of information as a lack of conformity remains to be seen.

Member states are, as already mentioned, free to regulate the 'effects' of contracts. This rather vague expression can be found in national legislation, seemingly without any generally accepted meaning. ${ }^{* 21}$ For our purpose, one example suffices: the new provision on change of circumstances in the French civil code (imprévision, Article 1195) belongs to the chapter on the effects of contracts. Such rules, as well as - for example - the German rules on Störung der Geschäftsgrundlage and on termination for a compelling reason, and the 'general clause' of contract law found in the Nordic countries, ${ }^{* 2}$ obviously may be maintained or introduced in national laws, quite independent of the SGD. The rules vary from country to country and the seller must be prepared for different outcomes. What happens, say, with the contract for the sale of an expensive car if there is an extraordinary rise in market prices for such cars between conclusion of the contract and delivery? And what if it turns out after conclusion of the contract that the car does not meet the environment standards in the consumer's home country? The proposal for a common European law was meant to harmonise even rules on such issues (CESL, Article 89). ${ }^{* 3}$

Closely connected with the rules on change of circumstances are rules on the consumer's right to damages, not least regarding the seller's possible excuses for a lack of conformity. The consumer's right to damages is mentioned in the recitals of the SGD as an 'essential element of sales contract', and it is stated that

18 Rome I Regulation (fn. 2), articles 10 and 6.

19 References regarding consumer sales: (Denmark) lov om køb LBK nr. 140 af 17/02/2014 (Sale of Goods Act, originally from 1906), Section 76(3); (Finland) konsumentskyddslag 20.1.1978/38 (Consumer Protection Act), Section 4:14; (Iceland) lög um neytendakaup 2003 nr. 48 20. mars (Consumer Sales Act), Section 17 (cf. Section 16(1)(b)); (Norway) lov 21. juni 2002 nr. 34 om forbrukerkjøp (Consumer Sales Act), Section 16(1)(b) (cf. Section 17); (Sweden) konsumentköplag 1990:352 (Consumer Sales Act), Section 16(3)(2) (cf. Section 17). See also K. Lilleholt, 'Application of General Principles in Private Law in the Nordic Countries', Juridica International 2013, pp. 12-19. - DOI: http://dx.doi.org/10.12697/issn1406-1082.

20 See, for example, H. Beale, 'Pre-Contractual Obligations: The General Contract Law Background', Juridica International, vol. XIV, no. I 2008, pp. 42-50. - DOI: http://dx.doi.org/10.12697/issn1406-1082; see also comparative notes in C. von Bar and E. Clive eds., Principles, Definitions and Model Rules of European Private Law. Draft Common Frame of Reference (DCFR). Full Edition, 6 vols., Munich 2009, pp. 469-471. - DOI: https://doi.org/10.1515/9783866537279.

21 See, for example, the French civil code (livre III, titre III, sous-titre I, chapitre IV); the Italian civil code (libro quarto, titolo II, capo V). In the Draft Common Frame of Reference, there is Chapter 9 in Book II, on 'contents and effects of contracts'.

22 Germany: civil code $\S \S 313$ and 314; Denmark: lov nr. 242 af 8 . maj 1917 om aftaler og andre retshandler på aftalerettens område, most recently published as "LBK nr. 193 af 02/03/2016"; Finland: lag om rättshandlingar på förmögenhetsrättens område 13.6.1929/228; Iceland: lög 1936 nr. 71.febrúar 1926 um samningsgerð, umboð og ógilda löggerninga; Norway: lov 31. mai $1918 \mathrm{nr} .4$ om avslutning av avtaler, om fuldmagt og om ugyldige viljeserklæringer; Sweden: lag (1915:218) om avtal och andra rättshandlingar på förmögenhetsrättens område (Section 36 in each of these acts). See also comments in Lilleholt, 'Application of General Principles in Private Law in the Nordic Countries'.

23 See also the discussion in N. Jansen and R. Zimmermann, Commentaries on European Contract Laws, Oxford University Press: Oxford 2018, pp. 899-918. 
the consumer should be 'entitled to claim compensation to any detriment caused by an infringement by the seller of this Directive' (Recital 61). Still, the rules on damages are left to national laws, with the rather over-optimistic justification that 'the existence of such a right to damages is already ensured in all Member States' (Recital 61). It is well known that the rules vary throughout Europe with regard to damages as a remedy for non-performance of contractual obligations, and a seller must be prepared to deal with different regimes in different countries also in this respect. ${ }^{* 24}$ In comparison, the proposal for a common European sales law had rules also on this subject (CESL, Chapter 16).

Member states are free to regulate 'the consequences of the termination of a contract, in so far as they are not regulated in this Directive' (SGD, Article 3, para 6). The main consequences of a termination are regulated in the SGD's Article16, para 3: the buyer must return the goods to the seller, and the seller must reimburse the consumer for the price paid. The provision then states that '[f]or the purposes of this paragraph, Member States may determine the modalities for return and reimbursement'. The combined effect of Article 3, para 6 and Article 6, para 3 is not quite clear. Does the latter provision restrict national rules on return and reimbursement to 'modalities', and - in that case - what does the word 'modalities' mean? A practical issue is the extent to which the seller must pay interest on the money received and the buyer pay for the use made of the goods (see, for comparison, Article 174 CESL). Is this a 'modality' of return and reimbursement, and - if not - are the rules of the directive exhaustive on this matter, restricting the freedom laid down in Article 3, para 6 to regulate this issue as 'consequences of the termination of a contract'? Arguably, the best answer is that interest on money and payment for use can be regulated in national laws. If this is correct, the seller must be prepared to find different rules in each country.

\section{National rules on the consumer's obligations under the contract}

The SGD does not regulate the buyer's obligations under a sale of goods contract or the remedies for nonperformance of such obligations. This is the case also for the 1999 consumer sales directive. However, the effect of leaving out rules on this half of the contractual relationship becomes more conspicuous with a total harmonisation directive like the SGD. The balance of a contractual relationship always depends on the reciprocity of the parties' obligations. Again, the party risking surprises because of foreign rules is the seller - in most cases, the law of the consumer's home country governs the entire contract.

One example only will be highlighted in this article, namely the seller's right to require performance of the buyer's obligation to pay the price. In some countries, the seller cannot require performance of paying the price if the consumer terminates ('cancels') the contract prior to delivery. The seller is left with a claim for damages. ${ }^{*}{ }^{25}$ In some other countries, the seller can require performance, in principle. ${ }^{*} 26$ The CESL had an exception for situations where the seller could reasonably have made a substitute transaction (Article 132). Admittedly, making a substitute transaction and claiming damages will in most cases be the practical reaction anyway - independent of the seller's formal rights - if the consumer is unwilling to receive the goods. It is still useful for the seller to be aware of the relevant rules and to take them into account when formulating the general sales conditions offered to customers.

24 See, for example, Jansen and Zimmermann, Commentaries on European Contract Laws (fn. 23), pp. 1435-1442.

25 See, for example, Finland: konsumentskyddslag 20.1.1978/38 (Consumer Protection Act), Section 5:25; Iceland: lög um neytendakaup 2003 nr. 48 20. mars (Consumer Sales Act), Section 41; Norway: lov 21. juni 2002 nr. 34 om forbrukerkjøp (Consumer Sales Act), Section 41; Sweden: konsumentköplag 1990:352 (Consumer Sales Act), Section 37. See also K. Lilleholt, "The Draft Common Frame of Reference and "Cancellation" of Contracts', Juridica International, vol. XIV, no. 12008 , pp. 111-117. - DOI: http://dx.doi.org/10.12697/issn1406-1082.

26 See the comparative notes in von Bar and Clive, eds., Principles, Definitions and Model Rules of European Private Law. Draft Common Frame of Reference (DCFR). Full Edition (fn. 20), pp. 826-828; see also Jansen and Zimmermann, Commentaries on European Contract Laws (fn. 23), pp. 1189-1202. 


\section{Concluding remarks}

The examples given in this article show that the new consumer sales directive assessed as contract law legislation is incomplete, and that total harmonisation has not been possible even for the selected matters regulated by the directive. The legislative process in the Parliament resulted in several amendments that allow for national fine-tuning of the rules, for supplementary rules, and even for rules that deviate from the directive. Total harmonisation has thus not been achieved even for these selected topics for regulation. The broad harmonisation of the CESL - in the form of an optional instrument - turned out to be politically unattainable. The SGD illustrates that harmonisation is challenging enough also for the quite limited scope of a consumer sales directive. It seems that the idea of strong Europeanisation of contract law is on hold. 